\title{
Distribution and environmental risk of microplastics pollution in freshwater of Citarum Watershed
}

\author{
Kunny Izza Indah Afkarina ${ }^{1}$, Setyo Sarwanto Moersidik ${ }^{1 *}$, and Suyud Warno Utomo ${ }^{1}$ \\ ${ }^{1}$ School of Environmental Science, Universitas Indonesia, Central Jakarta 10430, Indonesia.
}

\begin{abstract}
The Citarum River is one of the most polluted rivers in the world because of the inadequate waste management system and community ignorance. Plastic is one of the contaminants in the Citarum watershed. In general, plastics less than $5 \mathrm{~mm}$ in size are defined as microplastics. Microplastics are persistent and harm the environment. This article aims to determine the potential for pollution and distribution of microplastics in freshwater systems, especially in the Citarum watershed area. Using a combination of literature study methods with Geographical Information Systems (GIS) analysis, this article explains that microplastic contamination has occurred along the Citarum watershed from upstream to downstream, found in water and sediment and fish samples. Facilitated by their small size and high stability in the environment, microplastics can move from the aquatic environment into the food chain and cause longterm damage. This case causes a severe threat to the quality of freshwater in the Citarum watershed. Therefore, this article can be used as a reference for managing pollution in the Citarum watershed area.
\end{abstract}

\section{Introduction}

The Citarum River is one of the most polluted rivers in the world. On the other hand, the Citarum River plays a vital role as raw water for Regional Drinking Water Companies (PDAM), supplying electricity in Java-Bali, and providing irrigation water for rice fields in West Java [1]. The Citarum River has been polluted by rubbish from the upstream. The inadequate waste management system and the community's behavior that makes the river a place for waste disposal and garbage are the leading causes of garbage pollution in the river [2]. Therefore, the government launched the Citarum Harum program. Citarum Harum is the Citarum River restoration program initiated by the central government in January 2018. Its main target is to free the Citarum River from the waste of factories, households, agriculture, and livestock for the next seven years [3]. Entering the Citarum Harum program's third year, plastic pollution in this $279 \mathrm{~km}$ river has not been resolved [4].

\footnotetext{
*Corresponding author: ssarwanto@eng.ui.ac.id
} 
Plastic litter can be degraded into micro-sized fragments, which is harmful to aquatic organisms. In general, plastics fewer than $5 \mathrm{~mm}$ in size are characterized as microplastics [5]. There are two types of microplastics in the environment, primary microplastic particles, as well as microbeads from daily domestic products (such as toothpaste and detergents) [6], and secondary microplastics particles such as fragmentation of larger size plastics because of physical and chemical degradation processes [7]. In recent years, microplastics have been identified in freshwater environments, such as streams [8], lakes [9], and reservoirs [10]. These microplastics are persistent and have long-term effects when introduced into the aquatic environment [6] - the smaller volume of microplastics, the higher chances of absorption. Ingested microplastics can cause complex negative impacts on aquatic organisms [11].

Most of the studies on microplastics focus on the marine environment, whereas the research focus on freshwater accounts for less than $4 \%$ of the total studies reported [12]. On the other hand, the abundance of microplastics in freshwater is not much different from the marine environment [13]. Based on this background, this article aims to analyze the potential risk for microplastics pollution and distribution in the freshwater system, especially the Citarum watershed area.

\section{Method}

This article used a descriptive research method with a quantitative approach based on previous studies (literature studies), e.g., journal papers and conference papers. This analysis is strengthened by spatial data analysis using Geographical Information Systems (GIS) to make factual and accurate descriptions and relationships of the observed phenomena. This descriptive analysis was carried out by describing the abundance of microplastics and their distribution in the Citarum watershed area and analyzing the environmental risk base on theoretical analysis due to microplastics pollution in the freshwater environment.

\section{Results and discussion}

\subsection{Microplastics at Citarum Watershed}

The Citarum watershed is the primary watershed in West Java, which has 6,614 km2, with the main river having a river length of $297 \mathrm{~km}$. The geographical location of the Citarum River is $106^{\circ} 51^{\prime} 366^{\prime \prime}-107^{\circ} 51$ 'East Longitude and $7^{\circ} 19^{\prime}-6^{\circ} 24^{\prime} \mathrm{LS}$ [14]. The Citarum River is used as a water supply for irrigation purposes, raw water for PDAM, and industrial needs. The land use around the Citarum watershed is in settlements, agriculture, and fisheries [1]. The Citarum watershed has three large reservoirs used to supply water for irrigation, fisheries, and a Hydro Power Plant (PLTA), that is Saguling Reservoir, Cirata Reservoir, and Jatiluhur Reservoir, which provide almost $20 \%$ of Java-Bali's electrical energy needs [15]. The position and role of the Citarum watershed are crucial, but this strategy is not followed by good land management, thus affecting the hydrological characteristics of the watershed [16]. 

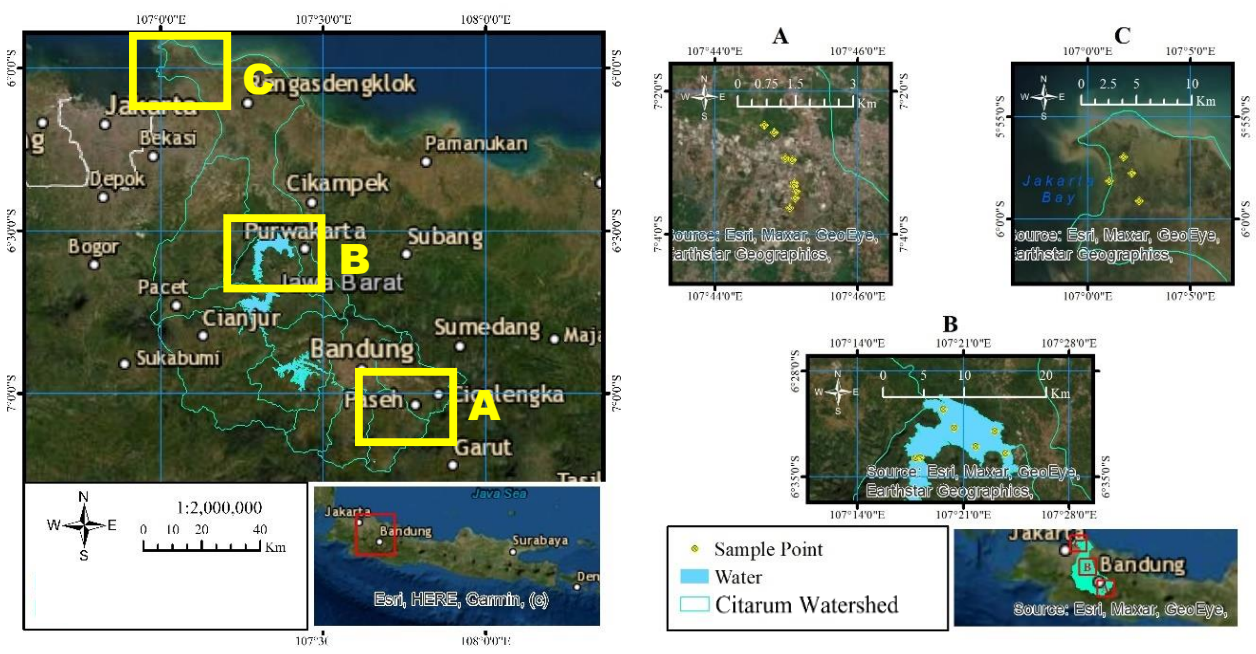

Fig 1. Sample Locations in The Citarum Watershed (A) Ciwalengke River (B) Jatiluhur Reservoir (C) Muara Gembong [17-19]

A study of microplastics pollution in the Citarum watershed area (Fig. 1) shows that the Citarum watershed has been contaminated by microplastics from upstream to downstream and is found in various samples such as water samples, sediments, and fish organs because synthetic microplastics have buoyancy and persistence in waters [20]. Freshwater, such as rivers and reservoirs, are direct recipients of runoff from the city, industrial, and agricultural area [21]. Lots of sources can cause microplastics pollution in freshwater environments, as well as effluent from Wastewater Treatment Plants (WWTP) [22] and runoff surfaces [23].

Table 1. Study of Microplastics Pollution in the Citarum watershed area [17-19]

\begin{tabular}{|c|c|c|c|c|c|}
\hline \multirow{2}{*}{ Location } & \multicolumn{2}{|c|}{ Dominant Microplastics } & \multirow{2}{*}{ Size } & \multirow{2}{*}{ Sample } & \multirow{2}{*}{ Average Concentrations } \\
\hline & Shape & Polymer Type & & & \\
\hline \multirow{2}{*}{$\begin{array}{l}\text { Ciwalengke } \\
\text { River }\end{array}$} & \multirow[b]{2}{*}{ Fiber } & \multirow{2}{*}{$\begin{array}{l}\text { Polyester and } \\
\text { nylon }\end{array}$} & \multirow{2}{*}{$\begin{array}{l}50- \\
2000 \\
\mu \mathrm{m}\end{array}$} & Water & $\begin{array}{l}5.85 \pm 3.28 \text { particles per } \\
\text { liter }\end{array}$ \\
\hline & & & & Sediment & $\begin{array}{l}3.03 \pm 1.59 \text { microplastic } \\
\text { particles per } 100 \mathrm{~g} \text { of dry } \\
\text { sediments }\end{array}$ \\
\hline $\begin{array}{l}\text { Jatiluhur } \\
\text { Reservoir }\end{array}$ & Fragment & $\begin{array}{l}\text { Polyethylene } \\
\text { and } \\
\text { polypropylene } \\
\end{array}$ & $\begin{array}{l}125- \\
5000 \\
\mu \mathrm{m}\end{array}$ & Water & $2.58 \times 10^{5}$ Particles per $\mathrm{km}^{2}$ \\
\hline \multirow{3}{*}{$\begin{array}{l}\text { Muara } \\
\text { Gembong }\end{array}$} & \multirow{3}{*}{$\begin{array}{l}\text { Fragment } \\
\text { and Fiber }\end{array}$} & \multirow{3}{*}{$\begin{array}{l}\text { Polyethylene } \\
\text { and } \\
\text { polypropylene }\end{array}$} & \multirow{3}{*}{$\begin{array}{l}125- \\
5000 \\
\mu \mathrm{m}\end{array}$} & Water & $0.0574 \pm 0.025$ particles $/ \mathrm{m}^{3}$ \\
\hline & & & & Sediment & $\begin{array}{l}16.666 \pm 0.577 \\
\text { particles } / 100 \mathrm{~g} \text { of dry } \\
\text { sediments }\end{array}$ \\
\hline & & & & $\begin{array}{l}\text { Fish } \\
\text { Gut and gill } \\
\text { Tissue }\end{array}$ & $\begin{array}{l}1.333 \pm 0.577 \text { Particles/fish } \\
1.111 \pm 0.838 \text { Particles/fish }\end{array}$ \\
\hline
\end{tabular}

Ciwalengke River is located in the upper stream of the Citarum watershed, which is a densely populated area and a textile industrial area. Microplastics pollution in the Ciwalengke River area is caused by the poor management of sewage treatment from the 
community and factories in the area [17]. This microplastics is confirmed by the dominant polymers found in polyester and nylon (Table 1). These polymers are widely used as raw material for synthetic fibers. Synthetic fibers account for about $60 \%$ of total global fiber production [24]. Thus, the more demand for production, the higher the level of pollution if not appropriately handled.

Microplastics were also found in the Jatiluhur Reservoir (Table 1). Jatiluhur Reservoir is the largest reservoir in the Citarum watershed area. The Jatiluhur Reservoir can function as the main container for microplastics in freshwater ecosystems because microplastic fragments can continue to accumulate and be stored for an extended period. On the other hand, the reservoir can also be a source of microplastic pollutants for downstream watersheds [10] because of their higher microplastic content. The dominant microplastics found in the Jatiluhur Reservoir area are fragments from freshwater aquaculture nets [18].

Plastic pollution in the upstream area of the Citarum watershed will have an impact on water quality downstream. Muara Gembong is the downstream area of the Citarum before entering sea waters [25]. Microplastics contamination in Muara Gembong was detected in water samples, sediments, and milkfish that cultivated using water from the Citarum River and marine waters (Table 1). However, there is no correlation between microplastic concentration in water and sediment with a microplastic concentration in milkfish. However, the presence of microplastics in each sample originating from various points in the sampling area should be noted for both local government and residents [19].

Based on the distribution of microplastics data in the Citarum watershed area, microplastic pollution comes from primary microplastics and secondary microplastics. One of the primary microplastic pollution sources is the textile industry. So far, it can be said that the awareness of textile entrepreneurs about environmental conditions is still low. It can be seen that around the Citarum watershed, there are several textile companies whose industrial WWTPs are not run optimally [26], and there are also several factories that dispose of their waste directly into the river [27]. Meanwhile, the source of secondary microplastic pollution comes from the fragmentation of domestic waste. The potential for waste generation in the Citarum River basin is high. In Bandung City, it reaches 1,501 tons per day, Bandung Regency 1,105 tons per day, Cimahi City 292.91 tons per day, Karawang Regency 785.6 tons per day, and Bekasi City 1,500 tons per day [3]. Secondary microplastic pollution can also be generated by the fragmentation of freshwater fish cage nets cultivated in three reservoirs along the Citarum watershed [18,28].

\subsection{Environmental Risk of Microplastics Pollutant}

Microplastics are persistent pollutants with a significant percentage in freshwater environments [20], which can be harmful to aquatic ecosystems. Aquatic organisms can accidentally eat microplastics because of the microplastics' similarity size and color with their natural prey [29]. Microplastic consumption has been found in a variety of aquatic organisms representing different trophic levels. Microplastics digested by organisms at lower trophic levels, like zooplankton, can overtake the food chain when eaten by organisms at higher trophic levels [30]. Microplastics can cause mechanical and chemical damage when ingested by aquatic organisms. Microplastics' consumption by organisms can cause mechanical damage, such as adhering to polymers, thus inhibiting mobility and clogging the digestive tract. Meanwhile, microplastic polymers' chemical damage to organs can cause inflammation, stress liver function, decrease growth rate, and impact the reproductive process [6].

Plastic materials can contain various additives used in the production of plastic materials, including Bisphenol A (BPA) and phthalates. BPA and phthalates potentially affect the endocrine system of aquatic organisms, affecting mobility, reproduction, and 
organism [31]. Another toxicity impact caused by microplastics pollution is an increase in chemical compounds such as persistent organic pollutants (POPs) and heavy metals [32]. When aquatic organisms ingest microplastics, they can cause POPs and chemicals' transfer, which are harmful to those organisms' metabolism. These compounds can increase the level of toxicity in aquatic organisms [33].

Humans can consume microplastics through drinking water and consuming fish exposed to microplastics. WWTPs are inefficient to altogether remove the microplastic particles in treated water [34]. Thus, microplastic particles can contaminate river water, which is used as a source of PDAM. Microplastic compounds can have long-term effects on human health [35]. Microplastic particles can impact human health, with the toxicity effect of chemicals absorbed from the environment or additives used in the production of plastic materials. Based on the United Nations' research data, more than $50 \%$ of plastics are accompanied by harmful monomers, additives, and chemical products [36].

\section{Conclusion}

This article includes discussing pollutant concentrations at several points along the Citarum watershed and the risk of pollution in the aquatic environment. Based on a literature study, it can be concluded that microplastic pollution has occurred along the Citarum watershed from upstream to downstream. Facilitated by their small size and high stability in the environment, microplastics can move from the aquatic environment into the food chain and cause long-term damage. Microplastic pollution is currently a critical environmental issue. Based on the research results, it is necessary to have integrated microplastic pollution management in the Citarum watershed by the government, private sector, and the community. Future research is expected to examine the same types of samples from upstream to downstream to obtain comprehensive data.

\section{Acknowledgements}

This research is Part of and funded by Publikasi Terindeks Internasional (PUTI) Prosiding Universitas Indonesia with contract number NKB-1268/UN2.RST/HKP.05.00/2020.

\section{References}

1. A. W. Utami, Water Quality of Citarum River J. Chem. Inf. Model. 53, 1689 (2019) doi: 10.1017/CBO9781107415324.004.

2. M. Sholeh, P. Pranoto, S. Budiastuti, and S. Sutarno, Analysis of Citarum River pollution indicator using chemical, physical, and bacteriological methods, AIP Conf. Proc. 2049, (2018) doi: 10.1063/1.5082473

3. M. W. Ritonga, Kompas (2020) https://kompas.id/baca/nusantara/2020/02/20/satgasdidorong-ambil-andil-pengelolaan-sampah-domestik/.

4. T. M. Sinaga, Kompas (2020) Kompas, 2020. https://kompas.id/baca/nusantara/2020/01/09/penanganan-sampah-jadi-fokus-citarumharum-2020/.

5. A. L. Andrady, Microplastics in the marine environment, Mar. Pollut. Bull. 62, 1596 (2011) doi: 10.1016/j.marpolbul.2011.05.030.

6. H. S. Auta, C. U. Emenike, and S. H. Fauziah, Distribution and importance of microplastics in the marine environmentA review of the sources, fate, effects, and potential solutions, Environ. Int. 102, 165 (2017) doi: 10.1016/j.envint.2017.02.013.

7. C. M. Rochman, A. Tahir, S. L. Williams, D. V Baxa, R. Lam, J. T. Miller, F. Teh, S. 
Werorilangi, and S. J. Teh, Anthropogenic debris in seafood: Plastic debris and fibers from textiles in fish and bivalves sold for human consumption, Nature Publishing Group, August, 1-10. (2015) doi: 10.1038/srep14340.

8. A. A. Koelmans, N. H. Mohamed Nor, E. Hermsen, M. Kooi, S. M. Mintenig, and J. De France, Water Research. 155, 410 (2019) doi: 10.1016/j.watres.2019.02.054.

9. C. M. Free, O. P. Jensen, S. A. Mason, M. Eriksen, N. J. Williamson, and B. Boldgiv, Mar. Pollut. Bull. 85, 156 (2014) doi: 10.1016/j.marpolbul.2014.06.001.

10. W. Yuan, X. Liu, W. Wang, M. Di, and J. Wang, Microplastic abundance, distribution and composition in water, sediments, and wild fish from Poyang Lake, China, Ecotoxicol. Environ. Saf. 170, 180 (2019) doi: 10.1016/j.ecoenv.2018.11.126.

11. J. Ding, S. Zhang, R. M. Razanajatovo, H. Zou, and W. Zhu, Accumulation, tissue distribution, and biochemical effects of polystyrene microplastics in the freshwater fish red tilapia (Oreochromis niloticus), Environ. Pollut. 238, 1 (2018) doi: 10.1016/j.envpol.2018.03.001

12. M. Wagner and S. Lambert, Freshwater Microplastics - The Handbook of Environmental Chemistry 58, Freshwater Microplastics. 302 (2018) doi: 10.1007/9783-319-61615-5.

13. J. Peng, J. Wang, and L. Cai, Current understanding of microplastics in the environment: Occurrence, fate, risks, and what we should do, Integrated Environmental Assessment and Management. 13, 476 (2017) doi: 10.1002/ieam.1912.

14. A. B. Supangat and P. Paimin, Study of the Role of Reservoir as Control of Natural Water Quality, Forum Geografi. 21, 123 (2016) doi: 10.23917/forgeo.v21i2.2357.

15. K. Yoshida, K. Tanaka, K. Noda, K. Homma, M. Maki, C. Hongo, H. Shirakawa, and $\mathrm{K}$. Oki, Quantitative evaluation of spatial distribution of nitrogen loading in the citarum river basin, Indonesia, J. Agric. Meteorol. 73, 31 (2017) doi: 10.2480/agrmet.D-15-00020.

16. R. K. Tukayo, Changes in Land Use in Citarum Watershed and Its Impact on Irrigation Water Supply, Institut Pertanian Bogor, (2011)

17. F. C. Alam, E. Sembiring, B. S. Muntalif, and V. Suendo, Microplastic distribution in surface water and sediment river around slum and industrial area (case study: Ciwalengke River, Majalaya district, Indonesia), Chemosphere 224, 637 (2019) doi: 10.1016/j.chemosphere.2019.02.188.

18. A. H. Ramadan and E. Sembiring, Occurrence of Microplastic in surface water of Jatiluhur Reservoir, E3S Web Conf. 148, 1 (2020) doi: 10.1051/e3sconf/202014807004.

19. E. Sembiring, A. A. Fareza, V. Suendo, and M. Reza, The Presence of Microplastics in Water, Sediment, and Milkfish (Chanos chanos) at the Downstream Area of Citarum River, Indonesia, Water, Air, and Soil Pollution. 231, (2020) doi: 10.1007/s11270-020-04710-y.

20. P. Singh and V. P. Sharma, Integrated Plastic Waste Management: Environmental and Improved Health Approaches, Procedia Environ. Sci. 35, 692 (2016) doi: 10.1016/j.proenv.2016.07.068.

21. M. Eriksen, N. Maximenko, M. Thiel, A. Cummins, G. Lattin, S. Wilson, J. Hafner, A. Zellers, and S. Rifman, Plastic pollution in the South Pacific subtropical gyre, Mar. Pollut. Bull. 68, 71 (2013) doi: 10.1016/j.marpolbul.2012.12.021.

22. A. McCormick, T. J. Hoellein, S. A. Mason, J. Schluep, and J. J. Kelly, Microplastic is an abundant and distinct microbial habitat in an urban river, Environ. Sci. Technol. 48, 11863 (2014) doi: 10.1021/es503610r.

23. L. Frère, I. Paul-Pont, E. Rinnert, S. Petton, J. Jaffré, I. Bihannic, P. Soudant, C. Lambert, and A. Huvet, Influence of environmental and anthropogenic factors on the composition, concentration and spatial distribution of microplastics: A case study of 
the Bay of Brest (Brittany, France), Environ. Pollut. 225, 211 (2017) doi:

10.1016/j.envpol.2017.03.023.

24. B. M. C. Almroth, L. Åström, S. Roslund, and H. Petersson, Quantifying shedding of synthetic fibers from textiles; a source of microplastics released into the environment, Environ. Sci. Pollut. Res. 25, 1191 (2018) doi: 10.1007/s11356-017-0528-7.

25. N. Fatimah, Composition and Abundance of Macroplastics and Microplastics in Water at the Citarum River Estuary, Bekasi Regency, West Java Province, Institut Pertanian Bogor, (2019)

26. D. Marganingrum, D. Roosmini, and A. Sabar, River Pollutant Sources Differentiation Using Pollution Index Method (Case Study : Upper Citarum Watershed), Riset Geologi dan Pertambangan 23, 41 (2013)

27. A. Sudradjat, The Role of Industry and Textile Products in the Conservation of Environmental Resources of the Citarum Watershed, Jurnal Teknologi Lingkungan 3, 92 (2002)

28. Krismono and L. P. Astuti, Management of Cascade Reservoirs (Saguling, Cirata, Jatiluhur) for Fish Cultivation in Floating Net Cages Prosiding Seminar Nasional Ikan IV, Jatiluhur, 29-30 Agustus 200629 (2006)

29. S. L. Wright, R. C. Thompson, and T. S. Galloway, The physical impacts of microplastics on marine organisms: a review, Environ. Pollut. 178, 483 (2013) doi: 10.1016/j.envpol.2013.02.031.

30. P. C. H. Hollman, H. Bouwmeester, and R. J. B. Peters, Microplastics in the Aquatic Food Chain; Sources, Measurement, Occurrence, and Potential Health Risks (Wageningen, 2013) http://edepot.wur.nl/260490.

31. M. Cole, P. Lindeque, C. Halsband, and T. S. Galloway, Microplastics as contaminants in the marine environment: A review, Mar. Pollut. Bull. 62, 2588 (2011) doi: 10.1016/j.marpolbul.2011.09.025.

32. T. de S. e. S. Pegado, K. Schmid, K. O. Winemiller, D. Chelazzi, A. Cincinelli, L. Dei, and T. Giarrizzo, First evidence of microplastic ingestion by fishes from the Amazon River estuary Mar. Pollut. Bull. 133, 814 (2018) doi: 10.1016/j.marpolbul.2018.06.035.

33. I. R. Sofi, J. Manzoor, R. A. Bhat, and R. Munvar, Plastic Pollution and the Ecological Impact on the Aquatic Ecosystem 80 (2019) doi: 10.4018/978-1-52259452-9.ch005.

34. P. L. Ngo, B. K. Pramanik, K. Shah, and R. Roychand, Pathway, classification and removal efficiency of microplastics in wastewater treatment plants, Environ. Pollut. 255, (2019) doi: 10.1016/j.envpol.2019.113326.

35. M. Pivokonsky, L. Cermakova, K. Novotna, P. Peer, T. Cajthaml, and V. Janda, Occurrence of microplastics in raw and treated drinking water, Sci. Total Environ. 643, 1644 (2018) doi: 10.1016/j.scitotenv.2018.08.102.

36. D. Lithner, A. Larsson, and G. Dave, Environmental and health hazard ranking and assessment of plastic polymers based on chemical composition, Sci. Total Environ. 409, 3309 (2011) doi: 10.1016/j.scitotenv.2011.04.038. 